ks. Jarosław M. Lipniak

Papieski Wydział Teologiczny we Wroctawiu

DOI: $10.15290 /$ std.2016.02.13

\title{
MAŁŻEŃSTWO W TEOLOGII ORTODOKSYJNEGO KOŚCIOŁA KOPTYJSKIEGO
}

\section{MATRIMONY IN THEOLOGY OF THE COPTIC ORTHODOX CHURCH}

The Coptic Orthodox Church relates the mystery of trinity unity not only to science about the Church but also to perception of matrimony. The matrimony is for Copts one of seven sacraments. People were appointed to live in image and likeness of the Holy Trinity and will of God is, so as they, with exception of special cases, do not live in loneliness but in family. Like God gave first family his blessing and said to Adam and Eve to be fertile and have increase (Gen 1,28 ), so the Coptic Church gives its blessing relationship of man and woman. The matrimony is not for Orthodoxy only a state of nature but also a state of grace. Life in marriage, like monastic life is a vocation, requiring specific gift or charisma of the Holy Spirit and just this gift is being given in the sacrament of matrimony.

Key words: matrimony, sacrament, the Coptic Church.

Teologia sakramentu małżeństwa w Ortodoksyjnym Kościele Koptyjskim jest na gruncie polskiej literatury teologicznej swoistego rodzaju terra incognita. Opracowania na ten temat są nieliczne. Być może spowodowane jest to brakiem kodyfikacji kanonicznej tego sakramentu w samym Kościele koptyjskim oraz trudnościami wynikającymi z dotarciem do jego teologicznych źródeł.

Ortodoksyjny Kościół Koptyjski należy do grupy Kościołów orientalnych zwanych Kościołami przedchalcedońskimi. Według Tradycji, Kościół w Egipcie 
został założony przez św. Marka ${ }^{1}$ Tamtejsza wspólnota chrześcijańska rozwijała się pod rządem patriarchów Aleksandrii, których zwano również papieżami² Kościół w Egipcie wytworzył własny obrządek, odmienny zarówno od rzymskiego, jak i od bizantyjskiego. Kościół egipski wydał wielu wybitnych teologów, zasłużonych zwłaszcza w walce z herezją nestorianizmu. Do najwybitniejszych z nich należą Klemens Aleksandryjski i Orygenes. To właśnie w Egipcie narodził się chrześcijański monastycyzm, na początku w formie pustelnictwa. Z tym wiążą się imiona egipskich Świętych Antoniego i Pachomiusza3.

Rozłam w Kościele egipskim nastąpił po Soborze w Chalcedonie (451). Ówczesny patriarcha aleksandryjski Dioskur odrzucił wyznanie wiary uznające istnienie dwóch natur w Jezusie Chrystusie. Swego patriarchę poparła przeważająca większość wiernych Egiptu. Jego zwolennicy nazwali się „prawowiernymi" (gr. orthodoxos, co akurat w tym przypadku nie znaczy, jak zazwyczaj, „prawosławni”), natomiast przeciwnicy - melchitami (aram.-gr. melchitoi „ludzie króla”), a później „katolikami” (gr. katholikos „powszechny”). W pierwszym okresie rozłamu nie pojawiła się druga linia patriarchów aleksandryjskich - patriarchowie pozostali głową zarówno jednego, jak i drugiego odłamu Kościoła egipskiego, usiłując godzić zwaśnione strony ${ }^{4}$. Godność tę sprawowali zarówno Koptowie, jak i melchici. Z biegiem czasu coraz częściej zdarzało się jednak, że panowało dwóch patriarchów jednocześnie - koptyjski i melchicki. W następnych wiekach rozdział obu Kościołów koptyjskich jeszcze się pogłębił. Zaczęto uważać się nawzajem za heretyków i wzajemnie się zwalczać. Powstały dwie linie patriarchów Aleksandrii.

Wierni, którzy uznali Sobór Chalcedoński, przez kolejne wieki zachowywali łączność i z Rzymem i z Konstantynopolem, mimo że kulturowo należeli do kręgu bizantyjskiego. Po Wielkiej Schizmie Wschodniej w roku 1054 egipscy melchici stopniowo odchodzili od jedności ze Stolicą Apostolską, stając się częścią Cerkwi prawosławnej6.

Iris Habib el Masri, The story of the Copts: The true story of Christianity in Egypt, St. Anthony Coptic Orthodox Monastery 1982.

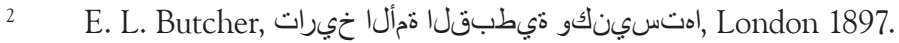

3 Uznawani za Świętych przez Kościół katolicki, Kościół anglikański, Kościoły prawosławne i Koptyjski Kościół Ortodoksyjny. Niektóre Kościoły protestanckie uważają ich za bohaterów wiary. Kościół luterański zalicza ich do odnowicieli Kościoła.

4 Y. N. Youssef, Severus of Antioch in the „History of the Patriarchs”, „Parole de l'Orient” 28 (2003), s. 435-458.

5 J. M. Lipniak, The Catholic Church in the Middle East, Jerusalem 2014, s. 43n.

6 Idem, Sakrament matżeństwa w teologii Ortodoksyjnego Kościoła Koptyjskiego, [w:] Ekumeniczna wizja matżenstwa i rodziny. Szansa i życiowe problemy, J. M. Lipniak (red.), Wrocław 2015, s. 147. 


\section{Małżeństwo sakramentem}

Tajemnica trynitarnej jedności w odmienności odnosi się w teologii Ortodoksyjnego Kościoła Koptyjskiego nie tylko do eklezjologii, ale również do pojmowania sakramentu małżeństwa. Małżeństwo jest dla Koptów jednym $z$ siedmiu sakramentów? ${ }^{7}$ Sakrament ten jest nie tylko umową prawną, lecz ma głęboki wymiar duchowy i jest niezbędny dla Kościoła ${ }^{8}$. Mężczyzna i kobieta zostali stworzeni na obraz Trójcy Świętej i wolą Stwórcy jest, aby, z wyjątkiem szczególnych przypadków, żyli nie w samotności, lecz w rodzinie ${ }^{9}$. Dlatego Bóg im pobłogosławił w słowach: „Bądźcie płodni i rozmnażajcie się, abyście zaludnili ziemię i uczynili ją sobie poddaną” ( $\operatorname{Rdz} 1,28)$. Podobnie Kościół koptyjski błogosławi swoich wiernych zawierających sakrament małżeństwa podkreślając, że nie jest on jedynie stanem natury, ale dzięki Chrystusowi stanem łaski. Życie w małżeństwie, podobnie jak życie monastyczne, jest szczególnym powołaniem, dlatego wstępujący na tę drogę życia otrzymują specjalną łaskę.

Sakramentalne małżeństwo w swoim wymiarze duchowym wskazuje, że mężczyzna i kobieta, którzy noszą w sobie Ducha Świętego, tworzą od tej chwili jedną świątynię ${ }^{10}$. Jest to realizacja tego, o czym pisał św. Mateusz: „Dlatego mężczyzna opuści ojca i matkę i połączy się ze swoją żoną, i będą oboje jednym ciałem. Tak więc już nie są dwoje, lecz stanowią jedno" (Mt 19, 5-6). Stąd w Kościele koptyjskim nupturienci muszą być tej samej wiary, bo tylko w ten sposób mogą zbudować prawdziwy domowy Kościól. Nie powinno się zawierać związków z przedstawicielami innych wyznań, bo straciłoby się poprzez połączenie dwóch sprzecznych poglądów doskonałość własnej wiary ${ }^{11}$.

\section{Cele małżeństwa}

Ortodoksyjny Kościół Koptyjski stawia przed małżeństwem trzy cele ${ }^{12}$ : Pierwszym z nich jest współpraca między mężczyzną a kobietą. Małżonkowie są równi, mają sobie pomagać i wspierać we wszystkim. Kobieta i mężczyzna zostali stworzeni jako jednakowo ważni ${ }^{13}$. W życiu i powołaniu do świętości jest równość kobiety i mężczyzny. Dlatego na pierwszym miejscu w teologii

\footnotetext{
$7 \quad$ Bishop Mettaous, Sacramental Rites in the Coptic Orthodox Church, s. 119.

8 Shenouda III, So Many Years With People's Questions, t. IV, Cairo 1992, s. 65.

9 Ibidem, s. 83.

10 Ibidem, s. 65.

11 Ibidem, s. 83.

12 Bishop Mettaous, Sacramental Rites..., op. cit., s. 119.

13 Ibidem.
} 
koptyjskiej jest wspólpraca małżonków, wzajemne pomaganie sobie, wspólne podejmowanie obowiązków rodzicielskich i wychowawczych oraz wspólne dorastanie do świętości. Zgodnie z zamierzeniem Stwórcy, mężczyzna i kobieta zostali stworzeni na obraz i podobieństwo Boże. Na pierwszym miejscu jest więc miłość i rozwój małżonków. Uzupełnianie się w dążeniu do Królestwa Bożego ${ }^{14}$.

Drugim celem małżeństwa koptyjskiego jest prokreacja. Dzieci też są celem małżeństwa, ale nie najważniejszym. Kościół koptyjski podkreśla, że prokreacja ma za zadanie zachowanie ludzkości przed zagładą oraz jest nagrodą od Boga ${ }^{15}$. Małżonkowie są wezwani do szczególnej współpracy z Bogiem w stwarzaniu nowego życia. Bóg, który dał płodność człowiekowi, zaprosił go do współpracy w stwarzaniu nowego człowieka. Kobieta „zostanie zaś zbawiona przez rodzenie dzieci" (1 Tm 2, 15). Pan Bóg stwarza, a rodzice przekazują życie swojemu dziecku, dlatego ojcostwo jest obowiązkiem mężczyzny, a macierzyństwo odpowiedzialnością kobiety ${ }^{16}$.

Miłość małżonków nigdy nie powinna zamykać się na nowe życie. Dzieci powinny być radością i szczęściem oraz wzmacniać związek małżeński zgodnie $z$ tym, co czytamy w Psalmach: „Oto synowie są darem Pana, a owoc łona nagrodą. Jak strzały w ręku wojownika, tak synowie za młodu zrodzeni. Szczęśliwy mąż, który napełnił nimi swój kołczan” (Ps 127, 3-5) oraz „Małżonka twoja jak płodny szczep winny we wnętrzu twojego domu. Synowie twoi jak sadzonki oliwki dokoła twojego stołu. Oto takie błogosławieństwo dla męża, który boi się Pana. Niechaj cię Pan błogosławi z Syjonu, oglądaj pomyślność Jeruzalem przez całe swe życie" (Ps 128, 3-5) ${ }^{17}$. Posiadanie potomstwa jest więc wielkim darem otrzymanym od Boga, nagrodą za małżeństwo. Niemniej jednak zdarzają się przypadki, że małżonkowie nie mogą doczekać się dzieci, wówczas Kościół koptyjski prosi swoich wiernych, aby się nie smucili ani nie popadali w rozpacz, lecz z pokorą przyjęli wolę Pana w postawie całkowitego zaufania i zawierzenia Jego miłości. Małżonkowie powinni uświadamiać sobie, że posiadanie potomstwa nie jest najważniejszym celem zawartego przez nich sakramentu ${ }^{18}$. Niepłodność nie jest więc powodem do rozwodu czy stwierdzenia nieważności małżeństwa.

W odniesieniu do możliwości stosowania środków antykoncepcyjnych i innych sposobów kontroli urodzin w Kościele koptyjskim istnieją różne opinie. W przeszłości kontrola urodzin była zdecydowanie potępiana, ale obecnie

\footnotetext{
14 J. M. Lipniak, Sakrament matżeństwa..., op. cit., s. 148-149.

15 Bishop Mettaous, Sacramental Rites..., op. cit., s. 119.

16 Shenouda III, Words of Spiritual Benefit, t. III, Cairo, 1991, s. 31

17 Bishop Mettaous, Sacramental Rites..., op. cit., s. 119.

18 Ibidem, s. 119-120.
} 
mniej rygorystyczny pogląd zaczyna przeważać. Wielu koptyjskich teologów i ojców duchowych uważa, że rozsądne użycie środków antykoncepcyjnych w małzeństwie nie jest samo w sobie grzeszne. Ich zdaniem o ilości dzieci i o odstępach, w jakich powinny przychodzić na świat, najlepiej rozstrzygają sami rodzice, kierując się głosem swego sumienia.

Przerywanie ciąży natomiast, jest przez koptyjską teologię moralną jednoznacznie potępiane. Nie mamy prawa niszczyć ludzkiego życia ${ }^{19}$.

Trzecim celem jest ochrona przed cudzołóstwem i rozpustą. Kościół koptyjski traktuje małżeństwo jako swoistego rodzaju lekarstwo na ludzkie słabości. Kierując się nauczaniem św. Pawła z siódmego rozdziału Pierwszego Listu do Koryntian zauważa, że ze względu na niebezpieczeństwo rozpusty mężczyzna powinien posiadać żonę, a kobieta męża. Małżeństwo traktowane jest więc jak lekarstwo na ludzkie słabości ${ }^{20}$. Stosunek płciowy jest darem od Boga, jednak dar ten udzielony został jedynie mężczýnie i kobiecie, którzy pozostają w sakramentalnym związku małżeńskim ${ }^{21}$. Z tego właśnie powodu Kościół koptyjski nie akceptuje stosunków płciowych poza małżeństwem, nawet w przypadku, gdy partnerzy mają zamiar się pobrać ${ }^{22}$. Teologia koptyjska podkreśla jedność sakramentu małżeństwa przejawiającą się w monogamii.

Ortodoksyjny Kościół Koptyjski nie dopuszcza, rzecz jasna, możliwości błogosławienia związków między osobami tej samej płci.

\section{Zaręczyny}

Ortodoksyjny Kościół Koptyjski praktykuje zaręczyny czyli dobrowolne przyrzeczenie małżeństwa. Poprzedzają one małżeństwo, ale same sakramentem nie są. Bez tej dobrowolnej zgody nie może dojść do sakramentu małżeństwa. Narzeczony udaje się do narzeczonej i składa oświadczyny. W tym czasie narzeczeni i ich rodziny powinny ustalić kwestie dotyczące zaręczyn, ślubu, posagu i obowiązków każdej ze stron. Same zaręczyny odbywają się w kościele. Zaręczyny mają swoją liturgię, w czasie której kobieta stoi po prawej stronie mężczyzny (symbol pochodzenia Ewy z prawego boku Adama) oraz śpiewany jest Psalm 45. W czasie liturgii narzeczeni nakładają na palec prawej ręki pobłogosławione pierścionki zaręczynowe. Nakładanie pierścionka na prawą rękę ma symbolizować, że kobieta w niedalekiej przyszłości stanie się prawą

\footnotetext{
19 J. M. Lipniak, Sakrament małzeństwa..., op. cit., s. 148-149.

20 Bishop Mettaous, Sacramental Rites..., op. cit., s. 120.

21 Ibidem.

22 Ibidem.
} 
ręką mężczyzny oraz będzie go uczciwie i szczerze wspierała po ślubie ${ }^{23}$. Narzeczony nosi pierścionek z imieniem narzeczonej, a narzeczona pierścionek $z$ imieniem narzeczonego. Pierścionki powinny być ze złota lub innego szlachetnego kruszcu. Zaręczeni, po zakończonej liturgii, otrzymują od kapłana stosowny certyfikat, na którym zapisane zostają: imiona i nazwiska zaręczonych, ich wiek oraz proponowany termin ślubu ${ }^{24}$. Certyfikat zostaje podpisany przez narzeczonych i świadków oraz zatwierdzony przez kapłana.

Zaręczyny w Kościele koptyjskim są niezbędne do zawarcia sakramentalnego małżeństwa. W tym czasie narzeczeni mogą lepiej poznać siebie nawzajem, swoje myśli, motywacje, charaktery, osobowości, duchowość. Dla rodzin zaręczonych okres ten ma być czasem do współpracy i dobrego przygotowania się do ślubu. Narzeczeństwo nie może trwać dłużej niż rok. Jeśli okazałoby się, że zaręczeni nie znajdują wspólnego języka wówczas zaręczyny mogą zostać zerwane. W tym celu zaręczeni udają się do kapłana i podpisują w obecności świadków stosowny certyfikat. Zwracają pierścionki zaręczynowe, ewentualne prezenty i pieniądze $\mathrm{e}^{25}$.

\section{Miejsce i obrzęd zawarcia małżeństwa}

Sakrament małżeństwa udzielany jest w kościele. Wyjątkowo ze względu na prześladowania można go udzielić $\mathrm{w}$ domach. Ceremonia ślubna połączona jest z Eucharystią. Msza zaczyna się około godz. 17.00 albo $19.00^{26}$.

Trzeba zwrócić uwagę, że Koptowie poszczą blisko 210 dni w roku i w tych dniach nie odbywa się żadne wesele. Na przykład przed Narodzeniem Pańskim post zaczyna się 43 dni przed, czyli około 25 listopada i trwa aż do 7 stycznia - do Wigilii, później mamy Wielkanoc i także żadnych wesel nie ma (post 55 dni), w sierpniu obchodzimy post dla Matki Boskiej - 17 dni (od 6 sierpnia do 22 sierpnia), święto Zesłania Ducha Świętego - post 35 dni (początek czerwca do początku lipca), są jeszcze inne posty Kościoła koptyjskiego, np. Post św. Apostołów i Post Niniwy. Według prawa koptyjskiego nie można zawierać małżeństwa również w niedzielę poprzedzającą Wielki Post. Wynika to z duszpasterskiej troski i faktu, że wierni koptyjscy zobowiązani są przez pierwsze trzy dni po ślubie do modlitwy, postu i wstrzemięźliwości seksualnej ${ }^{27}$. Gdyby więc 23 Ibidem, s. 124.

24 Bishop Mettaous, Sacramental Rites..., op. cit., s. 128.

25 Ibidem.

26 J. M. Lipniak, Sakrament matżeństwa..., op. cit., s. 149.

27 Ta tradycja zachowywania postu, trwania na modlitwie i wstrzemięźliwości seksualnej wywodzi się z Księgi Tobiasza. Czytamy w niej o młodej kobiecie Sarze, która siedmiokrotnie wychodziła za mąż, ale nie mogła cieszyć się małżeństwem, gdyż w noc poślubną 
małżeństwo było udzielane w niedzielę poprzedzającą Wielki Post, wówczas ich abstynencja seksualna dochodziłaby do blisko dwóch miesięcy ${ }^{28}$.

Wstąpienie w związek małżeński jest bardzo ważnym momentem w życiu człowieka. Moment ten w praktyce Ortodoksyjnego Kościoła Koptyjskiego powinien nastąpić po odpowiednim przygotowaniu i głębokim namyśle. Dlatego Kościół koptyjski stawia warunek minimalnego wieku dla nupturientów: 18 lat dla mężczyzny i 16 lat dla kobiety. Warunek ten jest wynikiem troski, aby małżeńska przysięga została zrealizowana z pełną świadomością i odpowiedzialnością przez osoby dojrzałe zarówno fizycznie jak i psychicznie.

Istotnym elementem małżeństwa koptyjskiego jest obrzęd namaszczenia. Namaszczenia dokonuje kapłan po wymówieniu specjalnej modlitwy. Namaszcza najpierw oblubieńca, potem oblubienicę. Olej ma strzec przed demonami. Namaszczając głowę narzeczonego kapłan mówi: „Niech ten olej zniszczy demony. Olej ten jest przeciwko złym duchom, jest to olej świętych duchów. Niech zniszczy on duchy nieczyste. Przez Jezusa Chrystusa Króla Chwały". Namaszczając narzeczoną mówi: „Namaszczam Twoją głowę olejem abyś była jak kielich czystego wina". Olej używany w czasie ślubu jest traktowany jako pomoc do uwalniania ludzi od złych duchów i pokus, które czyhają na nupturientów w małżeństwie. Olej ma zniszczyć mocą Chrystusa demony i złe duchy. Wylanie oleju jest oznaką szacunku i ma na celu ukazanie obfitości Bożych dobrodziejstw. „Stół dla mnie zastawiasz na oczach mych przeciwników; namaszczasz mi głowę olejkiem; mój kielich jest przeobfity" (Ps 23,5; por 92, 11). Namaszczenie nowożeńców jest symbolem czystości i niezniszczalności, ma być bronią do walki z drapieżnymi myślami. Namaszczenie jest w końcu znakiem radości i wesela (Ps 45,7; Prz 27, 9). Olej w czasach Starego Testamentu był używany do namaszczenia królów, a częścią sakramentu małżeństwa w Kościele koptyjskim jest ukoronowanie małżonków, którzy stają się poprzez sakrament królem i królową domu ${ }^{29}$.

Po namaszczeniu następuje moment koronacji. Korony ślubne są wieńcami radości, podkreślają duchowy wymiar sakramentu, ale jednocześnie symbolizują korony męczeństwa. Małżeństwo bowiem oznacza także nieustanne

mężowie nagle umierali. Sprawcą ich śmierci był demon Asmodeusz. Tobiasz, który zakochał się we wdowie i poślubił ją, w noc poślubną posłuszny archaniołowi Rafałowi wraz ze swoją żoną trwa na modlitwie, pali serce i wątrobę ryby. Asmodeusz ucieka do Górnego Egiptu, a rankiem młoda para, ku zaskoczeniu wielu, pojawiła się żywa. Wspólna modlitwa małżeńska oraz zaproszenie Boga w czas współżycia seksualnego, pogłębiło u Tobiasza i Sary znaczenie aktu małżeńskiego. Dlatego w Kościele koptyjskim jest on rozumiany nie tylko jako znak wzajemnej miłości małżonków, ale przede wszystkim jako czas i miejsce obecności Boga. 
poświęcanie się sobie nawzajem. Nałożenie koron oznacza, że para staje się chwałą dla siebie. Doskonała żona jest koroną męża, a mężczyzna jest głową kobiety (por. 1 Kor 11,3). Nad ukoronowanymi głowami kapłan trzyma krzyż udzielając nowożeńcom błogosławieństwa. Następnie nakłada pięć łyżeczek kadzidła do kadzielnicy i okadza młodych.

Po koronacji następuje obrzęd nałożenia obrączek, które przewiązane są czerwoną wstążką symbolizującą więzi miłości, możliwej dzięki Krwi Chrystusa. Obrączki położone są na jedwabnej chusteczce, symbolizującej bezcenność małżeństwa. Obrączki noszone są na lewej ręce.

W czasie ślubu kapłan odmawia pięć modlitw, wykonywane są radosne pieśni, w tym hymn ku czci Najświętszej Maryi Panny, którą panna młoda powinna naśladować w czystości małżeńskiej, skromności, duchowości i w cnotach.

Pan młody ubierany jest następnie w kapę, która symbolizuje, że staje się panem domu. To do niego od tej chwili należeć będzie prawo i obowiązek prowadzenia modlitw przy domowym ołtarzu. Ma on też być żołnierzem Chrystusa, gotowym do walki o wiarę i życie wieczne (por. $1 \mathrm{Tm} 6,12$ ).

Nowo poślubieni otrzymują do rąk egzemplarz Pisma Świętego - znak przysięgi i obietnicy ${ }^{30}$. Rytuał ten ma przypominać, że mają przestrzegać prawa Bożego i żyć według Ewangelii ${ }^{31}$.

Kolejnym elementem ślubu koptyjskiego jest okadzenie nowożeńców. Okadzenie ma swoje ważne znaczenie w liturgii koptyjskiego małżeństwa. W Starym Testamencie w woni kadzidła Izrael widział wyraz uwielbienia, dla Boga (Mdr $18,21 ;$ Ps 141,20$)$. Spalanie kadzidła było równoznaczne $z$ kultem uwielbienia Boga, jak również modlitwą przebłagania (1 Krl 22, 44; 1 Mch 1, 55). Małżonkowie należą do Chrystusa i wraz z Nim tworzą jedno Ciało, w którym On jest Głową. Kadzidło, którym okadza się nowo zaślubionych spalając się, wydaje przyjemną woń jest także symbolem modlitwy. Psalmista, zwracając się do Boga w niebezpieczeństwie, prosił „Niech moja modlitwa jak kadzidło wznosi się przed Tobą" (Ps 140, 2), a św. Jan w Apokalipsie tak przedstawia swoje widzenie: „Ujrzałem... jak przyszedł anioł i stanął przy ołtarzu, mając złote naczynie na żar, i dano mu wiele kadzideł, aby dał je w ofierze jako modlitwy wszystkich świętych, na złoty ołtarz, który jest przed tronem. I wzniósł się dym kadzideł jako modlitwy świętych, z ręki anioła przed Bogiem” (Ap 8, 2-4).

Ortodoksyjny Kościół Koptyjski zaleca nowym małżonkom samodzielne życie poza domem rodziców czy teściów. Konieczność samodzielnego życia wynika z nakazu ewangelicznego: „Dlatego mężczyzna opuści ojca i matkę i połączy się ze swoją żoną, i będą oboje jednym ciałem” (Mt 19, 5). Przypomina

30 Bishop Mettaous, Sacramental Rites..., op. cit., s. 129.

31 T. Y. Malaty, Introduction to the Coptic Orthodox Church, Alexandria 1993, s. 239. 
równocześnie o obowiązku troski o rodziców, którym należy się zawsze głęboki szacunek.

\section{Przymioty małżenstwa}

Podobnie jak w Kościele katolickim, Kościół koptyjski za przymioty małzeństwa uznaje jedność ${ }^{32}$ i nierozerwalnośćc ${ }^{33}$.

Jedność małżeństwa oznacza związek jednego mężczyzny z jedną kobietą. Jedność w teologii Kościoła koptyjskiego sprzeciwia się wielożeństwu, poligamii czy homoseksualizmowi. Monogamiczne małżeństwo jest właściwe naturze ludzkiej i wynika z równości mężczyzny i kobiety. Miłość mężczyzny i kobiety dąży do jedności w osobowej wspólnocie „A tak już nie są dwoje, lecz jedno” (Mt 19, 6) i powołani są jako małżonkowie do wzrastania w tej jedności. Tworzą oni wspólnotę całego życia, dzielą cały program życia, to, co mają, i to, kim są. Jedność małżeńska powinna być pogłębiana wspólną modlitwą i uczestnictwem w Eucharystii. Małżonkowie oddają się sobie w miłości całkowitej, a przez to jedynej i wyłącznej. Ortodoksyjny Kościół koptyjski podkreśla, że sakrament małżeństwa to dar Boga i nie można tego daru niszczyć. Małżonkowie mają się wzajemnie wspomagać, nie tylko w życiu codziennym, ale też na drodze do Zbawienia oraz coraz bardziej przybliżać się do Boga, który jest źródłem miłości. Mimo różnych przeciwności, trwając w jedności małżeństwa, coraz bardziej zdążają do świętości ${ }^{34}$.

Do istoty małżeństwa koptyjskiego należy jego nierozerwalność. Prawdziwa miłość jest zawsze nieodwołalna, nie może być „miłością” na próbę. Nierozerwalność jest wolą samego Boga: „Co więc Bóg złączył, tego człowiek niech nie rozdziela!" (Mk 10, 9). Nierozerwalność powodowana jest również dobrem dzieci i stabilnością rodziny ${ }^{35}$.

\section{Małżeństwa między krewnymi}

Kościół koptyjski stanowczo zakazuje małżeństw z osobami blisko spokrewnionymi. Zastosowanie w tej materii ma Księga Kapłańska, która szczegółowo zabrania takich związków. „Nikt z was nie będzie się zbliżał do ciała swojego krewnego, aby odsłonić jego nagość. Ja jestem Pan! Nie będziesz odsłaniać nagości swojego ojca lub nagości swojej matki. Jest ona twoją matką - nie

\footnotetext{
32 Bishop Mettaous, Sacramental Rites..., op. cit., s. 120.

33 Ibidem, s. 121.

34 J. M. Lipniak, Sakrament matżeństwa..., op. cit., s. 151.

35 Bishop Mettaous, Sacramental Rites..., op. cit., s. 130.
} 
będziesz odsłaniać jej nagości. Nie będziesz odsłaniać nagości swojej macochy, bo to jest nagość twojego ojca. Nie będziesz odsłaniać nagości swojej siostry, córki twojego ojca lub córki twojej matki, bez względu na to, czy urodziła się w domu, czy na zewnątrz. Nie będziesz odsłaniać nagości córki twojego syna lub córki twojej córki, bo są one twoją nagością. Nie będziesz odsłaniać nagości córki żony twojego ojca, bo jest ona dzieckiem twojego ojca, jest twoją siostrą. Nie będziesz odsłaniać nagości siostry swojego ojca, bo ona jest krewną twojego ojca. Nie będziesz odsłaniać nagości siostry swojej matki, bo jest ona krewną twojej matki. Nie będziesz odsłaniać nagości brata swojego ojca: nie będziesz się zbliżał do jego żony, bo jest ona twoją ciotką. Nie będziesz odsłaniać nagości swojej synowej, bo jest ona żoną twojego syna, nie będziesz odsłaniać jej nagości. Nie będziesz odsłaniać nagości swojej bratowej, jest to nagość twojego brata. Nie będziesz odsłaniać nagości kobiety i jej córki. Nie będziesz brał córki jej syna ani córki jej córki, aby odsłonić jej nagość, bo są one jej ciałem. Byłaby to rozpusta! Nie będziesz brał kobiety razem z jej siostrą, aby odsłonić jej nagość za życia tamtej, byłoby to sposobnością do niezgody" (Kpł 18, 6-18) ${ }^{36}$.

\section{Rozwód}

Ortodoksyjny Kościół Koptyjski nie zezwala na rozwody. Niemniej jednak, powołując się na autorytet tekstu Ewangelii wedtug św. Mateusza 19, 9, gdzie Pan Jezus stwierdza: „Każdy, kto rozwodzi się z żoną z wyjątkiem przypadku rozpusty, a żeni się z inną, cudzołoży", Kościół koptyjski dopuszcza możliwość rozwodu i powtórnego małżeństwa w dwóch przypadkach. Pierwszym jest wspomniane już cudzołóstwo czyli zdrada małżeńska ${ }^{37}$. Drugim zaś wyjątkiem jest apostazja, którą chrześcijanie z Egiptu traktują jako duchową niemoralnośćc ${ }^{38}$. Teologia koptyjska zauważa, że skoro Chrystus, zgodnie z relacją Mateusza, dopuścił wyjątek od swego ogólnego orzeczenia o nierozerwalności małżeństwa, Kościół koptyjski również gotów jest dopuszczać odstępstwa od tej zasady ${ }^{39}$.

Małżeństwo, będące w Kościele koptyjskim sakramentem, jest darem łaski. Kościół dopuszcza jednak, że mężczyzna i kobieta mogli popełnić błąd, prosząc

36 Shenouda III, Contemplations on the Ten Commandments, t. IV, Cairo 1993, s. 32.

37 W V-VI wieku toczyły się w chrześcijaństwie spory o definicję małżeństwa. Dla katolicyzmu istotną rolę odegrała definicja rzymskiego prawnika Modestyna, podkreślająca zobowiązujący charakter przysięgi, która miała dbać o majątek małżonków. Ta forma przysięgi jest niemal taka sama jak w pogańskim Cesarstwie Rzymskim. Natomiast definicja, według której to miłość czyni sakrament małżeństwa, jest autorstwa wcale nie duchownego czy teologa, ale wschodniorzymskiego cesarza Justyniana.

38 J. M. Lipniak, Sakrament małżenstwa..., op. cit., s. 151.

39 Bishop Mettaous, Sacramental Rites..., op. cit., s. 127. 
o ten sakrament. Mogli wykluczać jego jedność i nierozerwalność. W takich wypadkach Kościół koptyjski dopuszcza, lecz nie zachęca, do powtórnego małżeństwa.

Papież koptyjski Szenuda III ${ }^{40}$ uwrażliwiał podległe mu duchowieństwo przed niebezpieczeństwem łatwego udzielania rozwodów kościelnych. Zwłaszcza, że niektóre osoby uciekają się do różnego rodzaju nadużyć, aby ów rozwód uzyskać. Fikcyjnie zmieniają np. wyznanie przechodząc na islam tak, aby w świetle prawa kościelnego i państwowego można było zalegalizować rozwód. Patriarcha Aleksandrii zauważa, że tylko autentyczna apostazja może być powodem rozwodu ${ }^{41}$. Dlatego też nie można błogosławić małżeństw osób rozwiedzionych $z$ innych powodów niż te, które zatwierdził Kościól. Poślubienie takiej osoby łączy się z cudzołóstwem ${ }^{42}$.

Związek małżeński uważa za dozgonny i nierozerwalny. Jego zerwanie postrzega jako tragedię spowodowaną przez ludzką słabość i grzech. Potępiając ten grzech, Kościół ciągle jednak pragnie okazać pomoc cierpiącym z jego powodu ludziom i umożliwić im powtórną szansę. Tak więc w przypadku, gdy małżeństwo całkowicie przestało być rzeczywistością, Kościół koptyjski nie nalega na zachowanie formalnej fikcji. Rozwód postrzegany jest jako wyjątkowe, ale nieuniknione ustępstwo wobec naszej ludzkiej słabości spowodowanej życiem w upadłym świecie. Jednakże, pomagając mężczyznom i kobietom podnieść się $z$ upadku, Kościół koptyjski zdaje sobie sprawę z tego, że powtórne małżeństwo nie może już mieć takiego samego charakteru jak pierwsze. Z tego też względu w nabożeństwie powtórnych zaślubin niektóre radosne ceremonie są całkowicie pomijane i zastępowane modlitwami pokutnymi ${ }^{43}$.

Słowa kluczowe: małżeństwo, sakrament, Kościół koptyjski.

\section{Bibliografia:}

1. Bishop Mettaous, Sacramental Rites in the Coptic Orthodox Church.

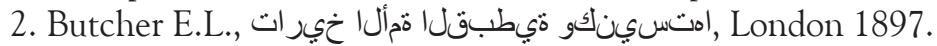

3. Iris Habib el Masri, The story of the Copts: The true story of Christianity in Egypt, St. Anthony Coptic Orthodox Monastery 1982.

40 J. M. Lipniak, Szenuda III - papież z Egiptu, [w:] Szenuda III, Święta Dziewica Maryja, Świdnica 2013, s. 36-41; T. Y. Malaty, The Pastoral Care. In the life of Pope Shenouda III, New York 2012.

41 Shenouda III, Contemplations on the Ten Commandments, op. cit., s. 30.

42 R. Shaham, Communal identity, political Islam and family law: Copts and the debate over the grounds for dissolution of marriage in twentieth-century Egypt, „Islam \& Christian Muslim Relations" 10(2010)21, s. 409-422.

43 J. M. Lipniak, Sakrament matżeństwa..., op. cit., s. 151-152. 
4. Lipniak J. M., The Catholic Church in the Middle East, Jerusalem 2014.

5. Lipniak J. M., Sakrament malżeństwa w teologii Ortodoksyjnego Kościoła Koptyjskiego, [w:] Ekumeniczna wizja matżeństwa i rodziny. Szansa i życiowe problemy, J. M. Lipniak (red.), Wrocław 2015.

6. Lipniak J.M., Szenuda III - papież z Egiptu, [w:] Szenuda III, Święta Dziewica Maryja, Świdnica 2013.

7. Malaty T. Y., Introduction to the Coptic Orthodox Church, Alexandria 1993.

8. Malaty T. Y., The Pastoral Care. In the life of Pope Shenouda III, New York 2012

9. Shaham R., Communal identity, political Islam and family law: Copts and the debate over the grounds for dissolution of marriage in twentieth-century Egypt, „Islam \& Christian - Muslim Relations" 10(2010)21

10. Shenouda III, Contemplations on the Ten Commandments, t. IV, Cairo 1993.

11. Shenouda III, So Many Years With People's Questions, t. IV, Cairo 1992.

12. Shenouda III, Words of Spiritual Benefit, t. III, Cairo, 1991.

13. Youssef Y. N., Severus of Antioch in the „History of the Patriarchs”, „Parole de l'Orient" 28 (2003). 